\title{
HUBUNGAN USIA DAN JENIS KELAMIN DENGAN KUALITAS HIDUP LANJUT USIA PENDERITA GOUT ARTHRITIS
}

\author{
Suri Salmiyati ${ }^{1}$, Lutfi Nurdian Asnindari ${ }^{2}$ \\ Program Studi Keperawatan \\ Fakultas Ilmu Kesehatan Universitas 'Aisyiyah Yogyakarta

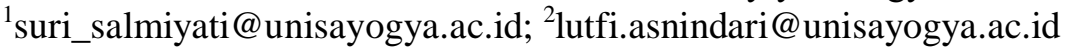

\begin{abstract}
Abstrak
Pendahuluan: Angka kejadian Gout Arthritis pada lanjut usia dari tahun ke tahun semakin meningkat. Ada banyak faktor yang mempengaruhi kualitas hidup lansia penderita Gout Arthritis. Faktor-faktor tersebut terdiri dari faktor demografi, faktor klinis dan psikologis. Usia dan jenis kelamin merupakan dua faktor demografi yang penting dalam menentukan kualitas hidup lansia dengan penyakit kronis.

Tujuan: Penelitian ini bertujuan untuk mengetahui hubungan faktor demografi yaitu usia dan jenis kelamin dengan kualitas hidup lansia dengan Gout Arthritis.

Metode: Metode penelitian merupakan penelitian deskriptif analitik korelasional dengan pendekatan waktu cross sectional dengan jumlah sampel 27 lanjut usia di dusun X Sonopakis Kidul Kasihan Bantul. Instrumen kualitas hidup dalam penelitian ini adalah The Short Form-36 (SF-36). Faktor demografi yang meliputi usia, jenis kelamin diukur menggunakan angket dan kartu identitas responden. Korelasi variabel diolah menggunakan Spearman rank.

Hasil: Hasil analisis data antara usia dengan kualitas hidup lansia didapatkan nilai p>0,05.

Kesimpulan: Kesimpulannya tidak ada hubungan usia dan jenis kelamin dengan kualitas hidup lansia dengan Gout Arthritis di dusun X Sonopakis Kidul Kasihan Bantul.
\end{abstract}

Kata Kunci: usia, jenis kelamin, kualitas hidup, gout arthritis

\begin{abstract}
Background: The number of Gout Arthritis in elderly increases per year. There are many factors influencing the life quality of elderly experiencing Gout Arthritis. The factors are demographic, clinical, and psychological factors. Age and gender are the two demographic factors playing significant role of elderly's life quality experiencing chronic disease.

Purpose: The study aims at investigating the relation of demographic factors namely age and gender and the life quality of elderly experiencing Gout Arthritis.

Methods: The study was a descriptive analytic correlational study with cross sectional approach. The samples were 27 elderly at $X$ village of Sonopakis Kidul Kasihan Bantul. The instrument of life quality in the study was The Short Form-36 (SF-36. Demographic factor includes age and gender which were measured using questionnaire and respondents' identity card. Variable correlation was analyzed using Spearman rank.

Results: The data analysis result between age and life quality of elderly showed that $\mathrm{p}>0.05$.

Conclusion: The result indicates that there is no relation of demographic factors namely age and gender and the life quality of elderly experiencing Gout Arthritis at $X$ village of Sonopakis Kidul Kasihan Bantul.
\end{abstract}

Keywords: age, gender, life quality, gout arthritis 


\section{Pendahuluan}

Penyakit Gout Arthritis berhubungan erat dengan gangguan metabolisme purin yang memicu peningkatan kadar asam urat dalam darah (hiperurisemia), yaitu jika kadar asam urat dalam darah lebih dari 7,5 mg/dl (Gliozzi, 2016). Angka kejadian Gout Arthritis dari tahun ke tahun semakin meningkat. Di Inggris didapatkan data 7\% pria yang berusia 65 tahun ke atas menderita Gout Arthritis dan merupakan radang sendi paling umum yang terjadi pada pria di negara-negara barat. Penelitian di Australia juga mendapatkan angka kejadian Gout Arthritis meningkat secara signifikan yaitu setidaknya 1,5\% dari populasi umum (Day et al, 2017). Data juga menunjukkan bahwa Gout Arthritis adalah masalah kesehatan masyarakat yang cukup besar di Amerika Serikat dan seluruh dunia (Singh, 2009).

Hasil Riset Kesehatan Dasar (Riskesdas) tahun 2013 menunjukkan prevalensi penyakit sendi berada di urutan ketiga penyakit tidak menular setelah stroke $(57,9 \%)$ dan hipertensi (36,8\%). Prevalensi penyakit sendi berdasarkan diagnosis meningkat seiring dengan bertambahnya usia. Berdasarkan Riskesdas tahun 2013, lanjut usia (lansia) di Yogyakarta yang menderita penyakit sendi sebanyak 51,9\% pada kelompok umur di atas 65 tahun dan sebanyak 54,8\% pada kelompok umur di atas 75 tahun (Riskesdas RI, 2013).

Gout Arthritis akut dan kronis akan menyebabkan rasa nyeri yang hebat, keterbatasan aktivitas fisik dan cacat, sehingga berdampak pada kualitas hidup yang berhubungan dengan kesehatan (Singh, 2009). Mempelajari kualitas hidup pada lansia dengan Gout Arthritis sangat penting. Perspektif lansia terhadap kualitas hidup biasanya akan berubah ketika mengalami penyakit kronis. Dengan mempelajari kualitas hidup lansia dapat dilakukan tindakan pencegahan terhadap peningkatan angka kesakitan pada lansia. (Amarantos, 2016).

Faktor demografi merupakan salah satu faktor yang mempengaruhi kualitas hidup lansia dengan gout arthritis. Faktor demografi tersebut terdiri dari jenis kelamin, usia, body mass index (BMI), waist-hip ratio (WHR), tempat tinggal, status pernikahan, pendidikan, status pekerjaan, pendapatan dan asuransi kesehatan. (Fu et al, 2017).

Faktor usia dan jenis kelamin merupakan faktor demografi yang jarang diteliti dihubungkan dengan kualitas hidup lansia, khususnya dengan Gout Arthritis. Hasil penelitian mendapatkan hasil bahwa nilai kualitas hidup akan menurun dengan penambahan usia dan adanya penyakit kronis yang diderita (Ćwirlej-Sozańska et al, 2018). Faktor sosiodemografi akan mempengaruhi kualitas hidup lansia dengan penyakit kronis. Berdasarkan hasil penelitian sebelumnya di Iran didapatkan bahwa kualitas hidup lansia berjenis kelamin wanita lebih buruk dibandingkan dengan pria. Kualitas hidup 
wanita yang lebih buruk pada wanita di Iran membutuhkan dukungan fisik, psikologis, dan sosial lebih lanjut pada lansia (Hajian-Tilaki, 2017). Berdasarkan latar belakang tersebut, rumusan masalah dalam penelitian ini adalah "Apakah ada hubungan usia dan jenis kelamin dengan kualitas hidup lansia dengan gout arthritis." Tujuan penelitian ini untuk mengetahui hubungan usia dan jenis kelamin dengan kualitas hidup lansia dengan gout arthritis.

\section{Metode}

Penelitian ini dilakukan dengan tahapan sebagai berikut : 1) Tahap Persiapan: Pengurusan ijin penelitian, ethical clearance penelitian 2) Tahap Pelaksanaan: Apersepsi dengan asisten penelitian, Melakukan informed consent dengan responden, Pengambilan data 3) Tahap Akhir: Analisa data, Penyusunan laporan, laporan hasil penelitian, Publikasi. Lokasi penelitian ini adalah di Dusun X Sonopakis Kidul Kasihan Bantul Yogyakarta.

Variabel penelitian ini adalah 1) Kualitas hidup lanjut usia dengan Gout Arthritis adalah tingkat dimana lanjut usia dengan Gout Arthritis menikmati hal-hal penting yang mungkin terjadi dalam hidupnya. Kualitas hidup dalam penelitian ini meliputi delapan komponen, yaitu faktor-faktor yang berhubungan dengan kualitas hidup lanjut usia dengan Gout Arthritis 2) Usia : Umur yang dihitung dari tanggal dilahirkan berdasarkan KTP, skala data rasio. 3) Jenis kelamin: Gender sesuai dengan KTP, skala data nominal laki-laki dan perempuan.

Populasi dalam penelitian ini adalah semua lansia yang berusia 60 tahun ke atas dan menderita Gout Arthritis yang tinggal di Dusun X Sonopakis Kidul Kasihan Bantul Yogyakarta pada bulan Juli-Agustus 2018. Sampel dalam penelitian ini diambil dengan metode total sampling, sehingga sampel dalam penelitian ini adalah sebanyak 27 orang. Jumlah tersebut lebih sedikit dari rencana karena terdapat lansia yang tidak masuk dalam kriteria inklusi. Kriteria inklusinya adalah : bersedia menjadi responden, pada saat dilakukan pengambilan data lansia tidak sedang ke luar kota dalam jangka waktu yang lama, dapat berkomunikasi dengan baik.

Penelitian ini merupakan penelitian deskriptif korelasional dengan pendekatan waktu cross sectional. Instrumen untuk mengukur usia dan jenis kelamin menggunakan daftar pertanyaan dan kartu identitas responden. Instrumen yang digunakan untuk mengukur kualitas hidup dalam penelitian ini dibuat dalam bentuk kuesioner The Short Form -36 (SF-36).

Penelitian ini sudah lolos uji etik dengan No 682/KEP-UNISA/IX/2018. Data diambil oleh peneliti dengan dibantu empat orang asisten yang telah diberikan penjelasan 
tentang instrumen yang akan digunakan. Peneliti melakukan pengambilan data ketika Posyandu Lansia sedang berlangsung. Akan tetapi, tidak semua lansia responden datang ke Posyandu sehingga pengambilan data dilakukan dengan mendatangi rumah lansia. Pengambilan data dilakukan 1 kali untuk semua variabel. Data diisi oleh peneliti dan asisten ke dalam kuesionar dengan cara menanyakan langsung kepada lansia, jawaban diisikan oleh peneliti dan asisten peneliti ke dalam kuesioner sesuai apa yang disampaikan oleh usia lanjut.

\section{Hasil}

Penelitian ini dilakukan pada Lansia di Dusun X Sonopakis Kidul Kasihan Bantul Yogyakarta. Hasil penelitian dapat diuraikan sebagai berikut:

\section{Karakteristik Responden}

Karakteristik responden dikategorikan berdasarkan status pernikahan, pendidikan, status pekerjaan. Deskripsi karakteristik responden penelitian dapat dilihat pada tabel berikut:

Tabel 1 Deskripsi Karakteristik Responden

\begin{tabular}{lcc}
\hline Karakteristik & $\begin{array}{c}\text { Frekuensi } \\
(\mathrm{f})\end{array}$ & $\begin{array}{c}\text { Persentase } \\
(\%)\end{array}$ \\
\hline Status Pernikahan & & \\
Memiliki Pasangan & 16 & 57,1 \\
Tidak Memiliki Pasangan & 12 & 42,9 \\
Total & 28 & 100 \\
& & \\
\hline Tingkat Pendidikan & 2 & 7,1 \\
SMA & 4 & 14,3 \\
SMP & 15 & 53,6 \\
SD & 7 & 25,0 \\
Tidak Sekolah & 28 & 100 \\
Total & 11 & 39,3 \\
Status Pekerjaan & 17 & 60,7 \\
Bekerja & 28 & 100 \\
Tidak Bekerja & & \\
Total & & \\
Berdasarkan tabel 1, status pernikahan sebagian besar responden memiliki pasangan \\
yaitu sebanyak 16 orang (57,1\%). Berdasarkan tingkat pendidikan, & sebagian besar \\
responden pendidikan SD yaitu sebanyak & 15 orang $(53,6 \%)$ Berdasarkan status \\
pekerjaan, sebagian besar responden tidak bekerja yaitu sebanyak 17 orang (60,7\%).
\end{tabular}


Berdasarkan hasil penelitian, usia dan jenis kelamin responden adalah sebagai berikut :

Tabel 2 Usia dan jenis kelamin

\begin{tabular}{lcc}
\hline Karakteristik & $\begin{array}{c}\text { Frekuensi } \\
(\mathrm{f})\end{array}$ & $\begin{array}{c}\text { Persentasi } \\
(\%)\end{array}$ \\
\hline Usia & & \\
$46-55$ & 1 & 3,6 \\
$55-65$ & 15 & 53,6 \\
$>65$ & 12 & 42,8 \\
Total & 28 & 100 \\
\hline Jenis Kelamin & \\
Laki-laki & 2 & 7,1 \\
Perempuan & 26 & 92,9 \\
Total & 28 & 100 \\
\hline
\end{tabular}

Berdasarkan tabel 2 usia responden mayoritas 55-65 tahun yaitu sebanyak 15 orang $(53,6 \%)$ dan jenis kelamin mayoritas perempuan yaitu 26 orang $(92,9 \%)$.

Berdasarkan hasil penelitian, kualitas hidup lansia dapat dikategorikan sebagai berikut: Tabel 3 Kategori Kualitas Hidup Lansia dengan Gout Arthritis

\begin{tabular}{ccc}
\hline Kualitas Hidup & Frekuensi & Persentasi \\
& $(\mathrm{f})$ & $(\%)$ \\
\hline Baik & 23 & 82,14 \\
Buruk & 5 & 17,85 \\
Total & 28 & 100 \\
\hline
\end{tabular}

Tabel 3 menunjukkan sebagian besar responden memiliki kualitas hidup dengan kategori baik yaitu sebanyak 23 orang $(82,14 \%)$.

Berdasarkan hasil uji statistik hubungan usia dan jenis dengan kualitas hidup, didapatkan hasil sebagai berikut :

Tabel 4 Hubungan usia dan jenis kelamin dengan kualitas hidup

\begin{tabular}{|c|c|c|c|}
\hline & & Uji Statistik & \\
\hline Usia & $\begin{array}{l}\text { Kualitas } \\
\text { hidup }\end{array}$ & Spearman & 0,270 \\
\hline Jenis Kelamin & $\begin{array}{l}\text { Kualitas } \\
\text { hidup }\end{array}$ & $\begin{array}{l}\text { Koefisien } \\
\text { Kontingensi }\end{array}$ & 0,096 \\
\hline
\end{tabular}

Keterangan : signifikansi, $\mathrm{p}<0,05$

Berdasarkan tabel 4 didapatkan hasil bahwa usia dan jenis kelamin tidak memiliki hubungan signifikan dengan kualitas hidup lansia dengan Gout Arthritis dengan nilai $\mathrm{p}>0,05$.

Penelitian ini mendapatkan bahwa tidak terdapat hubungan yang signifikan antara usia dengan kulitas hidup lansia penderita Gout Arthritis dengan nilai $p>0,05$. Hal tersebut berbeda dengan penelitian sebelumnya yang mendapatkan hasil terdapat hubungan yang negatif dan signifikan antara usia dengan kualitas hidup pasien (Widhani, 2013). 


\section{Pembahasan}

Penuaan akan memberikan dampak penurunan kualitas hidup lansia. Usia pada kelompok di atas 75 tahun merupakan prediktor kualitas hidup dibandingkan dengan kelompok yang lain. Banyak faktor positif dan negatif yang mempengaruhinya, akan tetapi hanya sedikit yang diketahui dapat mempengaruhi secara signifikan (Netuveli et al, 2006). Dampak usia terhadap kualitas hidup dapat terlihat hanya terdapat pada kelompok usia 75 tahun ke atas. Kualitas hidup terlihat meningkat pada usia 50-65 tahun dan sekitar usia 85 tahun kualitas hidup mulai menurun (Netuveli et al, 2006).

Hasil penelitian tersebut berbeda dengan penelitian ini hal tersebut kemungkinan dapat terjadi karena adanya perbedaan jumlah sampel. Selain itu, kualitas hidup dipengaruhi oleh banyak faktor yang mengakibatkan tidak ada satu faktor yang dapat dijadikan prediktor satu-satunya untuk melihat kualitas hidup lansia. Faktor usia cenderung memiliki pengaruh pada aspek fisik dari kulaitas hidup. Akan tetapi dalam penelitian ini, kualitas hidup dilihat secara umum tidak dibedakan per kelompok aspek yang ada dalam pengukuran menggunakan instrumen The Short Form -36 (SF-36).

Berdasarkan tabel 2 didapatkan bahwa tidak ada hubungan atara jenis kelamin dengan kualitas hidup lansia dengan Gout Arthritis dengan nilai $p>0,05$. Hasil ini berbeda dengan penelitian sebelumnya yang mendapatkan ada hubungan antara jenis kelamin dengan kualitas hidup. Penelitian mendapatkan bahwa lansia wanita memiliki kualitas hidup lebih tinggi dari lansia pria ((Netuveli et al, 2006). Kualitas hidup wanita turun karena beberapa faktor antara lain karena pekerjaan rumah tangga: perawatan yang bersifat informal, merawat rumah dan keluarga, dan kontak lebih sering dengan anakanak serta keluarga. Untuk pria tidak ada faktor-faktor tersebut yang signifikan. Beberapa perbedaan ini mungkin karena harapan hidup wanita yang lebih panjang, akibatnya ketika tinggal bersama pasangannya, wanita akan menjadi sosok yang merawat pria.

Akan tetapi, penelitian di Iran mendapatkan hasil yang berbeda, yaitu kualitas hidup lansia berjenis kelamin wanita lebih buruk dibandingkan dengan pria. Kualitas hidup wanita yang lebih buruk pada wanita di Iran membutuhkan dukungan fisik, psikologis, dan sosial lebih lanjut pada lansia (Hajian-Tilaki, 2017).

\section{Kesimpulan}

Tidak terdapat hubungan antara usia, jenis kelamin dengan kualitas hidup lansia dengan Artritis Gout di Dusun X Sonopakis Kidul Kasihan Bantul. 
Saran

Untuk peneliti selanjutnya adalah dengan menambahkan responden penelitian dan mengendalikan semua variabel pengganggu.

\section{Daftar Pustaka}

Amarantos E., Martinez A., Dwyer J. 2001. Nutrition and Quality of Life in Older Adults. The Journals of Gerontology: SERIES A, Vol. 56A (Special Issue II): 54-64. doi: https://doi.org/10.1093/gerona/56.suppl_2.54

Ćwirlej-Sozańska, A. B., Sozański, B., Wiśniowska-Szurlej, A., WilmowskaPietruszyńska, A. 2018. Quality of life and related factors among older people living in rural areas in south-eastern Poland. Annals of Agricultural and Environmental Medicine, 25(3), 539-545.doi: https://doi.org/10.26444/aaem/93847

Day, R. O., Frensham, L. J., Nguyen, A. D., et al. 2017. Effectiveness of an electronic patient centred self-management tool for gout sufferers: a cluster randomised controlled trial protocol. BMJ Open. 2017;7:e017281. doi:10.1136/ bmjopen-2017017281

Fu, T., Cao, H., Yin, R., et al. 2017. Associated factors with functional disability and health-related quality of life in Chinese patients with gout: a case-control study. BMC Musculoskeletal Disorders. 18:429

Gliozzi, M. Malara, N, Muscoli, S, Mollace,V. The treatment of hyperuricemia. 2016. Int J Cardiol. 213:23-7. doi: 10.1016/j.ijcard.2015.08.087. Epub 2015 Aug 8.

Hajian-Tilaki, K., Heidari B., 1 Hajian-Tilaki, A. 2017. Are Are Gender Differences in Health-related Quality of Life Attributable to Sociodemographic Characteristics and Chronic Disease Conditions in Elderly People?. Int J Prev Med. 8:95. doi: 10.4103/ijpvm.IJPVM_197_16

Netuveli G., Wiggins R. D., Hildon Z., Montgomery S. M., Blane D. 2006. Quality of life at older ages: evidence from the English longitudinal study of aging (wave 1). $J$ Epidemiol Community Health. 60:357-363. doi: 10.1136/jech.2005.040071

Riset Kesehatan Dasar (Riskesdas) RI. 2013. Badan Penelitian dan Pengembangan Kesehatan Kementrian Kesehatan Republik Indonesia. http://www.depkes.go.id/resources/download/general/Hasil\%20Riskesdas\%202013 .pdf . diakses tanggal 20 Maret 2018.

Singh J. A. 2009. Quality of Life and Quality of Care for patients with Gout. Curr Rheumatol Rep. 11(2): 154-160.

Widhani, R., D. 2013. Hubungan Usia dengan Kualitas Hidup Pasien Stroke Iskemik di RSUD Dr.Moewardi.https://digilib.uns.ac.id/dokumen/detail/33359/HubunganUsia-dengan-Kualitas-Hidup-Pasien-Stroke-Iskemik-di-RSUD-Dr-Moewardi. Diakses tanggal 7 Oktober 2018. 